\title{
Studi Evaluatif Terhadap Program Pembinaan Membaca Al- Qur'an Oleh PUSQIK IAIN Bengkulu
}

\author{
Khermarinah $^{1}$, Ediyansyah $^{2}$, Azizah Aryati $^{3}$ \\ IAIN Bengkulu \\ ${ }^{1}$ khermarina@iainbengkulu.ac.id, 2ediyansyah@iainbengkulu.ac.id, \\ 3azizaharyati@iainbengkulu.co.id,
}

Submitted: 2021-02-14 | Revised: 2021-06-22| Accepted: 2021-06-22

\begin{abstract}
The Qur'an conveys its call to all humans with different levels of thinking and ability of reason, some are directed to the heart so that they are open to receiving advice, some are directed to the mind to contemplate logical discussions, some contain facts that can easily be understood by all humans, and some are expressed in the form of parables so that only knowledgeable people can understand them. This field research with the qualitative descriptive method and evaluative approach aims to determine the implementation of the Al-Qur'an reading guidance program by PUSQIK IAIN Bengkulu. This research wants to discover the problems faced in this program and to describe the level of success of the program on the students' ability to read alQur'an. The findings of the study are 1. The implementation of the Al-Quran reading program by PUSQIK is conducted every Thursday, followed by all new students, and guided by expert lecturers in the field of Al-Quran. This activity lasts for one semester with an evaluation at the middle and end of the semester. 2. The problems in this program are a) Planning and learning designs that have not been implemented optimally, b) There is no agreement between managers, lecturers, and institutions regarding the Basic Competencies of each subject, which causes different learning outcomes also. c) There is no agreed subject to be used jointly by the lecturer in learning, d) The attendance of lecturers is less than $70 \%$ and the tardiness of the lecturers is more than $50 \%$, e) New students who have not been able to read the Qur'an correctly are more than 70\%. 3. Of the three Faculties, namely FEBI, FUAD, and Sharia, the graduation rate is below $50 \%$, only the Tarbiyah and Tadris faculties have graduated $50 \%$, meanwhile, the average pass rate is only $38.97 \%$.
\end{abstract}

Keywords: Evaluative Study, coaching reading Al-Quran, PUSQIK IAIN Bengkulu

Abstrak. Tujuan Al-Qur'an menyampaikan seruannya kepada semua manusia yang berbeda taraf berfikir dan kemampuan akalnya, ada yang diarahkan ke hati agar terbuka menerima nasehat, ada yang diarahkan ke akal agar merenungkan pembahasan logis, ada yang memuat hakikat yang dengan mudah dapat difahami oleh semua manusia, serta ada juga yang diutarakan dalam bentuk perumpamaan sehingga hanya orangorang berilmu yang bisa memahaminya. Penelitian lapangan dengan metode 
deskriptifkualitatif serta pendekatan evaluatif ini bertujuan untuk mengetahui pelaksanaan program pembinaan baca al-Qur'an oleh PUSQIK IAIN Bengkulu, mengetahui persoalan-persoalan yang dihadapi dan mendeskripsikan tingkat keberhasilan program tersebut terhadap kemampuan mahasiswa membaca al-Qur'an. Temuan penelitian adalah: 1.Pelaksanaan program membaca Al-Quran oleh PUSQIK dilaksanakan setiap Hari Kamis, diikuti oleh semua mahasiswa baru, dan dibimbing oleh dosen ahli dalam bidang Al-Quran. Kegiatan ini berlangsung selama satu semester dengan evaluasi pada pertengahan serta akhir semester. 2. Persoalan yang ada pada program ini adalah: a) Perencanaan dan rancangan pembelajaran yang belum dilaksanakan secara maksimal, b) Tidak adanya kesepakatan antara pengelola, dosen dan lembaga mengenai Kompetensi Dasar dari masing-masing pokok bahasan, yang menyebabkan capaian hasil belajar yang berbeda pula. c) Tidak adanya pokok bahasan yang disepakati untuk kemudian digunakan bersama-sama oleh dosen dalam pembelajaran, d) Kehadiran pengajar kurang dari $70 \%$ dan keterlambatan dosen lebih dari 50\%, e) Mahasiswa baru yang belum bisa membaca al-Qur'an dengan benar lebih dari 70\%. 3. Dari tiga Fakultas yaitu FEBI, FUAD dan Syariah tingkat kelulusan berada di bawah 50\%, hanya fakultas Tarbiyah dan Tadris saja yang mencapai kelulusan 50\%, Sementara itu tingkat kelulusan rata-rata hanya 38,97\%.

Kata Kunci: Studi evaluatif, pembinaan membaca Al-Quran, PUSQIK IAIN Bengkulu

\section{Pendahuluan}

Aktivitas kependidikan Islam di Indonesia pada dasarnya sudah berlangsung dan berkembang sejak sebelum Indonesia merdeka hingga sekarang. Hal ini dapat dilihat dari fenomena tumbuh kembangnya program dan praktik pendidikan Islam yang dilaksanakan di Nusantara, baik yang berupa pendidikan pondok Pesantren, pendidikan madrasah, pendidikan umum yang bernafaskan Islam, pelajaran pendidikan agama Islam yang diselenggarakan di lembaga-lembaga pendidikan umum sebagai suatu mata pelajaran atau mata kuliah saja, maupun pendidikan agama Islam yang diselenggarakan oleh kelompok-kelompok tertentu di masyarakat, serta tempat-tempat ibadah dan media massa. ${ }^{1}$

Sumber ajaran Islam, Al-Qur'an dan Sunnah Nabi, diletakkan pada posisi yang penting oleh umat Islam Indonesia kontemporer. Adalah biasa ditemukan kutipan al- Quran dan hadis dalam berbagai media informasi yang dicetak oleh, dan untuk, Muslim. Dalam kedua bentuk kutipan selalu diawali dengan tulisan Arab kemudian diikuti oleh terjemahan bahasa Indonesia. Masyarakat Muslim Indonesia terdiri dari pertama, Muslim yang memegang dan melaksanakan prinsip-prinsip ajaran Islam dalam kehidupan mereka sehari-hari. Kedua, Masyarakat Muslim yang memiliki komitmen terhadap ajaran Islam, menyadari atas makna dan batas-batas dari ajaran itu, dan berupaya untuk mengikuti prinsip-prinsip tersebut dalam kehidupan pribadi dan masyarakat. hlm.1

1 Muhaimin, Wacana Pengembangan Pendidikan Islam, (Yogyakarta: Pustaka pelajar, 2004), 
Ketiga, masyarakat muslim yang terdiri dari anggota masyarakat yang menjadi anggota organisasi-organisasi Islam yang melibatkan diri dalam bidang agama, kesejahteraan sosial, peribadatan dan dakwah, kegiatan politik dan masalahmasalah lainnya yang dirancang untuk meninggalkan suatu kesan masyarakat yang ekslusif. ${ }^{2}$

Al-Qur'an, sekalipun turun di tengah bangsa Arab dan dengan bahasa Arab, tetapi misinya tertuju pada seluruh umat manusia, tidak berbeda antara bangsa Arab dan non Arab, atau satu umat dengan umat lainnya ${ }^{3}$. Dan kami tidak mengutusmu, melainkan menjadi rahmat bagi seluruh alam. ${ }^{4}$ Al-Qur'an menyampaikan seruannya kepada semua manusia yang berbeda taraf berfikir dan kemampuan akalnya, ada yang diarahkan ke hati, agar terbuka menerima nasehat, dan ada yang diarahkan ke akal, agar merenungkan pembahasan logis, dan ada pula yang tertuju pada kedua-duanya, yang memuat hakikat yang dengan mudah dapat difahami oleh semua manusia, serta ada juga yang diutarakan dalam bentuk perumpamaan sehingga hanya orang-orang berilmu yang bisa memahaminya. ${ }^{5}$

Institut Agama Islam Negeri Bengkulu, yang merupakan salah satu lembaga pendidikan Islam mewajibkan semua mahasiswanya untuk mampu membaca al-Qur'an. Ada beberapa alasan yang melatarbelakangi kewajiban tersebut, antara lain ; Pertama, Al-Qur'an merupakan sumber dalam pendidikan Islam, karenanya mahasiswa harus dapat menggali nilai-nilai yang terkandung dalam al-Qur'an tersebut. Sebagai langkah awal untuk memahami isinya maka perlu kemampuan untuk membaca dan menulisnya, kedua, untuk mempermudah mahasiswa dalam mengikuti mata kuliah-mata kuliah selanjutnya yang terkait dengan al-Qur'an dan bahasa Arab. Ketiga, ketika seseorang menjadi alumni dari sebuah perguruan tinggi Islam, maka masyarakat akan beranggapan bahwa orang tersebut mahir membaca al-Qur'an dan pasti menguasai ilmu-ilmu agama Islam, oleh karenanya perguruan tinggi Islam tersebut harus berusaha untuk membuktikan bahwa anggapan tersebut benar adanya, keempat, sebagai bekal untuk mahasiswa ketika terjun ke masyarakat, baik untuk diri mereka sendiri dan keluarga maupun untuk masyarakat.

Karena pentingnya kemampuan membaca al-Qur'an, maka IAIN Bengkulu membuat beberapa kebijakan yang terkait dengan peningkatan kemampuan membaca Al-Qur'an. Tahun 2014 IAIN Bengkulu meningkatkan usaha tersebut dengan diadakannya program pembinaan baca al-Qur'an yang dikelola oleh Ma'had IAIN Bengkulu. Program tersebut diperuntukkan bagi semua mahasiswa baru selama dua semester, dibimbing oleh para dosen yang memiliki kemampuan dalam bidang baca tulis al-Qur'an, dan dilaksanakan setiap hari Kamis selama 90 menit. Dalam perjalanannya, program pembinaan

\footnotetext{
${ }^{2}$ Howard M. Federspiel, Kajian Al-Qur'an di Indonesia, (Bandung : Mizan, 1996) hlm.70-71

${ }^{3}$ M. Yusuf Musa, Al-Qur'an dan Filsafat, (Yogyakarta : Tiara Wacana, 1991) hlm. 1

${ }^{4}$ QS.Al-Anbiya' :107

${ }^{5}$ Ibid. Hlm. 2
} 
baca al-Qur'an tersebut mengalami beberapa persoalan yang berakibat pada kurang maksimalnya hasil yang dicapai oleh para mahasiswa, misalnya; pada saat tes membaca al-Qur'an sebagai salah satu syarat untuk mengikuti KKN, banyak mahasiswa yang tidak lulus, pada saat ujian komprehensif al-Qur'an yang merupakan salah satu syarat ujian munaqosah banyak mahasiswa yang tidak langsung lulus, dan pada saat diminta membaca al-Qur'an sebelum munaqosah banyak mahasiswa yang tidak mampu membaca al-Qur'an dengan baik dan benar.

Tujuan dari penelitian evaluatif ini adalah untuk menggali informasi tentang bagaimana pelaksanaan program pembinaan baca al-Qur'an di IAIN Bengkulu, apa saja persoalan-persoalan yang dihadapi dalam pelaksanaan program pembinaan baca al-Qur'an di IAIN Bengkulu, dan untuk mendeskripsikan tingkat keberhasilan program baca al-Qur'an oleh PUSQIK IAIN Bengkulu terhadap kemampuan baca al-Qur'an mahasiswa IAIN Bengkulu.

Penelitian yang terkait dengan al-Quran, metode mengajarkan al-Quran, atau kajian tentang ilmu-ilmu al-Quran lainnya mungkin sudah banyak dilakukan oleh para peneliti sebelumnya, misalnya Armah Aru (Malaysia, 1996) menemukan bahwa metode Iqra' sangat efektif dan baik untuk diterapkan karena ia mudah dipelajari dan menyebabkan murid semangat dalam mempelajari al-Qur'an. Kajian (Muslim 2008) dengan tajuk "Keberkesan pembelajaran baca tulis al-Qur'an menggunakan buku Al-Barqy di Taman Pendidikan Al-Qur'an Nurut-taqwa Malang", Berdasarkan analisis dokumen, secara keseluruhan kaedah al-Barqy mempunyai kesan yang baik terhadap murid dalam pengajaran dan pembelajaran al-Qur'an di lembaga tersebut. Dedi Fathurrahman dalam penelitiannya menemukan Ada empat langkah pengajaran al-Qur'an yang diterapkan pada zaman Rasulullah saw. 1)Membaca al-Qur'an dengan benar, 2) Menerangkan maksud, 3) Menghafal, 4) Mengamalkan ajaran al-Qur'an berdasarkan ajaran yang difahami daripada ayat-ayat yang dihafal. Model Pengajaran dan Pembelajaran al-Qur'an pada masa berikutnya di Indonesia ada banyak sekali di antaranya adalah, metodeiqra', metodeketukan dan metodeturutan. ${ }^{6}$

Perbedaan penelitian ini dengan penelitian sebelumnya adalah penelitian ini ingin melihat apakah program pembinaan membaca al-Quran yang dilaksanakan oleh Pusat Studi al-Quran dan Ibadah Kemasyarakatan (PUSQIK) IAIN Bengkulu telah berhasil meningkatkan kemampuan membaca al-Quran mahasiswa IAIN? Sehingga kalau seandainya program ini berhasil, mungkin program ini akan dijadikan model bagi perguruan tinggi lain dalam rangka meningkatkan kemampuan baca al-Quran para mahasiswanya.

6 http://dedifathurohmah.blogspot.co.id/2015/10/pengajaran-dan-pembelajaran-alQur'an.html. didownload tgl 07 Februari 2017. 
Penelitian ini berbentuk penelitian lapangan (Field Reaseach), sedangkanmetode yang digunakan adalah metode deskriptif. ${ }^{7}$ Kualitatif. ${ }^{8}$ Metode deskriptif dapat diartikan sebagai prosedur pemecahan masalah yang diselidiki dengan menggambarkan atau melukiskan keadaan subyek atau obyek penelitian pada saat sekarang berdasarkan fakta-fakta yang tampak atau sebagaimana adanya. Sedangkan metode kualitatif dalam penelitian ini dipahami sebagai prosedur penelitian yang dapat menghasilkan data deskriptif berupa kata-kata tertulis maupun lisan dari orang-orang atau pelaku yang dapat diamati. ${ }^{9}$ Menurut Sugiono, "Masalah dalam penelitian kualitatif bersifat sementara, tentative dan akan berkembang atau berganti setelah peneliti berada di lapangan". ${ }^{10}$ Pendekatan yang digunakan dalam penelitian ini adalah pendekatan evaluatif. Sebagai bagian dari evaluasi, penelitian evaluatif juga berfungsi sebagai evaluasi yaitu proses untuk mengetahui seberapa jauh perencanaan dapat dilaksanakan, dan seberapa jauh tujuan program tercapai. Kegiatan dalam penelitian evaluasi adalah membandingkan antara kegiatan yang direncanakan dengan kegiatan yang dilaksanakan, dan membandingkan antara tujuan program dengan hasil yang tercapai. Informasi yang diperoleh merupakan umpan balik yang dapat digunakan untuk penyempurnaan program. ${ }^{11}$

\section{Hasil dan Pembahasan}

\section{Pelaksanaan Program Pembinaan Baca Al-Qur'an di IAIN Bengkulu}

Pembinaan Membaca al-Qur'an di IAIN telah dilakukan sejak awal berdirinya IAIN. Dimulai dari pembentukan lembaga kajian al-Qur'an yang bernama LPTQ (Lembaga Pendidikan dan Tilawatil Quran) IAIN, yang bertugas membina mahasiswa dalam hal bacaan Quran. Lembaga ini mencari dan menjadwalkan dosen-dosen yang harus mengajar al-Qur'an di kelas-kelas. Satu kelas mahasiswa baru dibimbing oleh dua orang dosen. Mata kuliah membaca al-Qur'an dinamai Tahsinul Qiraah dan merupakan mata kuliah dengan beban 0 SKS.

Selanjutnya ketika LPTQ dianggap tidak berhasil meningkatkan kemampuan membaca al-Qur'an mahasiswa, pembinaan membaca Al-Quran bagi mahasiswa baru diambil alih oleh masing-masing fakultas, Tetapi cara inipun ternyata tidak membawa hasil yang signifikan bagi upaya peningkatan kemampuan membaca al-Qur'an bagi mahasiswa. Hal ini ditandai dengan masih banyaknya mahasiswa yang tidak lulus pada saat ujian komprehensif dan tidak

\footnotetext{
${ }^{7}$ Koentjaraningrat, Metode-Metode Penelitian Masyarakat, (Jakarta: Gramedia Edisi III, 1997), hlm. 29

${ }^{8}$ Robert C. Bogdan dan Steven Taylor, Introduction to Kualitatif reaseach Method, (New Jersey: John Willey and Son, 1984), h. 4.

${ }^{9}$ Robert C. Bogdan dan Steven Taylor, Introduction to Kualitatif reaseach Method, (New Jersey: John Willey and Son, 1984), h. 4.

${ }^{10}$ Sugiono, Memahami Penelitian kualitatif, (Bandung: Alfabeta, 2007), hlm. 238.

${ }^{11}$ Sugiyono, Metode Penelitian Manajemen, (Bandung: Alfabeta, 2015), hlm. 743.
} 
lulus saat seleksi baca Quran bagi mahasiswa yang akan KKN. Oleh karena itu kemudian IAIN mencoba menyerahkan pengelolaan pembinaan membaca alQur'an mahasiswa kepada Ma'had al-Jamiah (Pesantren Mahasiswa).

Pelaksanaan program membaca Al-Quran oleh PUSQIK dilaksanakan secara bersamaan setiap hari kamis pukul 07.30 di semua fakultas dan semua prodi. Semua mahasiswa harus mengikuti program ini di kelasnya masingmasing. PUSQIK menjadwalkan dosen-dosen yang dianggap ahli dalam hal membaca Al-Quran untuk mengajar di kelas-kelas semester 1 setiap Kamis pagi (dari pukul 07.30 s.d 09.10 WIB) Kegiatan ini berlangsung selama satu semester dan ada evaluasi setiap pertengahan dan akhir semester. Evaluasi dilakukan dengan cara ujian lisan atau tertulis pada pertengahan semester dan akhir semester serta adanya rapat evaluasi yang dihadiri oleh penyelenggara dan para pengajar.

\section{Persoalan-persoalan Yang Dihadapi Dalam Pelaksanaan Pembinaan Membaca al-Qur'an di IAIN Bengkulu}

a. Perencanaan Pembelajaran yang belum dilaksanakan secara maksimal.

Sebelum program pembelajaran dilaksanakan, perlu ada perencanaan terlebih dahulu, terkait dengan analisis kebutuhan materi apa yang akan diberikan kepada mahasiswa, penelusuran latar belakang kemampuan atau perilaku awal mahasiswa, yang bisa dilakukan dengan pre test, lalu mengelompokkan mahasiswa sesuai dengan kemampuan mereka agar mudah menyampaikan materi, menentukan metode dan strategi apa yang cocok bagi mahasiswa sesuai dengan kemampuan dan perilaku awal mereka, lalu menentukan kompetensi dasar dan standar kompetensi yang ingin dicapai, serta terakhir menentukan jenis evaluasi yang akan dilakukan untuk mengukur tercapainya SK dan KD pada saat akhir pembelajaran.

Perencanaan pembelajaran adalah seperangkat kegiatan yang dilakukan oleh seorang guru atau lembaga pendidikan sebelum dilaksanakannya proses belajar mengajar. Tujuan dari perencanaan pembelajaran adalah berlangsungnya proses pembelajaran sesuai dengan yang diinginkan atau berhasil mencapai target yang diinginkan. Ada empat unsur yang harus diperhatikan dalam perencanaan pembelajaran yaitu : pertama, untuk apa program tersebut dirancang? Kedua, Kemampuan apa yang ingin dicapai? Ketiga, bagaimana isi pelajaran atau keterampilan dapat dipelajari dengan baik? Atau metode dan kegiatan belajar mengajar apa yang akan digunakan? Keempat, bagaimana menentukan tingkat penguasaan pelajaran yang sudah dicapai? Atau menentukan tata cara evaluasi.

Ada sepuluh unsur yang diharuskan oleh Kemp untuk dipersiapkan pada perancangan pembelajaran, komponen tersebut adalah : 1) Perkiraan kebutuhan belajar untuk merancang suatu program pengajaran, nyatakan tujuan, kendala dan prioritas yang harus diketahui. 2) Pilih pokok bahasan atau tugas untuk dilaksanakan dan tunjukkan tujuan umum yang akan dicapai. 3) Teliti ciri 
siswa yang harus mendapat perhatian selama perencanaan. 4) Tentukan isi pelajaran dan uraikan unsur tugas yang berkaitan dengan tujuan. 5) Nyatakan tujuan belajar yang akan dicapai dari segi isi pelajaran dan unsur tugas. 6) Rancang kegiatan belajar mengajar untuk mencapai tujuan yang sudah dinyatakan. 7) Pilih sejumlah media untuk mendukung kegiatan pengajaran. 8) Rincikan pelayanan penunjang yang diperlukan untuk mengembangkan dan melaksanakan semua kegiatan dan untuk memperoleh atau membuat bahan. 9) Bersiap-siaplah untuk membuat evaluasi hasil belajar dan hasil program. 10) Tentukan persiapan siswa untuk mempelajari pokok bahasan dengan memberikan uji awal kepada mereka. ${ }^{12}$

Kesepuluh unsur di atas tidak dilakukan semua oleh PUSQIK. Dari hasil wawancara dengan para ketua jurusan, sekretaris jurusan, ketua prodi dan dekan di fakultas yang ada di IAIN, 87\% menyatakan bahwa mereka tidak pernah diajak atau dilibatkan dalam perencanaan pembelajaran. Yang terjadi selama ini adalah para ketua prodi, ketua jurusan dan dekan atau wakil dekan hanya menerima surat pemberitahuan melalui surat dari Ma'had atau PUSQIK bahwa akan ada program pembinaan membaca al-Qur'an atau matrikulasi alQur'an, prodi atau jurusan diminta untuk mengosongkan jam pertama di hari Kamis atau Jumat bagi mahasiswa semester I dan semester II.

Ketika hal ini ditanyakan kepada pengelola (Ma'had dan PUSQIK), mereka mengatakan bahwa sebetulnya para ketua prodi, ketua jurusan bahkan dekan atau wakil dekan satu sudah diundang untuk rapat persiapan pelaksanaan program matrikulasi al-Qur'an, hanya saja jarang yang datang, hanya beberapa saja yang datang atau hanya diwakili oleh pengelola prodi. Dari 42 orang dosen yang diundang, hanya 7 orang dosen yang datang. Dari semua ketua prodi/ketua jurusan yang diundang, hanya 1 orang yang datang, itupun diwakilkan kepada pengelola program studi. Mereka beralasan bahwa waktu rapat bersamaan dengan kegiatan lain, seperti rapat persiapan borang akreditasi, bersamaan dengan jadwal mengajar dan ada juga yang mengatakan undangan tidak sampai.

\section{b. Kurikulum}

Awalnya kurikulum diartikan sebagai sejumlah mata pelajaran di sekolah atau mata kuliah di perguruan tinggi yang harus ditempuh untuk mencapai suatu tingkat tertentu. ${ }^{13}$ Pada perkembangan selanjutnya kurikulum dipandang sebagai seluruh pengalaman belajar siswa. Konsep yang ditawarkan oleh Ronald Doll menunjukkan adanya perubahan lingkup, dari konsep yang sangat sempit ke konsep yang sangat luas. Pengalaman siswa yang dimaksud dapat berlangsung di

${ }^{12}$ Jerold E Kemp, Proses Perancangan Pengajaran, terjemahan Asril Marjohan (Bandung : Penerbit ITB, 1994) hlm. 13-14.

${ }^{13}$ Marvin D. Alcom and James M.Linely, Issus in Curriculum Development, (New York : World Book Co., 1959) hlm.3. 
sekolah, di rumah ataupun di masyarakat, bersama guru atau tanpa guru, berkenaan langsung dengan pelajaran ataupun tidak.

Beberapa ahli mengatakan bahwa kurikulum sebagai rencana pendidikan atau pembelajaran. Hilda Taba mengajukan konsep kurikulum yang tidak terlalu luas dan tidak pula terlalu sempit, ia mengungkapkan bahwa kurikulum adalah rencana pembelajaran yang terkait dengan proses dan pengembangan anak didik. Dari beberapa pendapat di atas sebagian pendapat menekankan pada isi atau mata pelajaran, sebagian menekankan pada proses atau pengalaman sedangkan pendapat lain memadukan dua pendapat tersebut, yaitu menekankan pada isi atau mata pelajaran, dan juga proses atau pengalaman. ${ }^{14}$

Ada lima komponen kurikulum yaitu, 1) tujuan pembelajaran, yang berfungsi menentukan arah dan corak kegiatan pendidikan, menjadi indikator dari keberhasilan pelaksanaan pendidikan dan menjadi pegangan dalam setiap usaha dan tindakan dari pelaksanaan pendidikan. ${ }^{15}$ 2) materi pembelajaran, 3) strategi pembelajaran, 4) Media pembelajaran, dan 5) Evaluasi pembelajaran.

Keahlian membaca al-Qur'an merupakan ciri khas IAIN dan lembaga pendidikan tinggi Islam lainnya. Kemampuan inilah yang membedakan antara alumni IAIN dan bukan alumni IAIN. Untuk Standar Kompetensi program matrikulasi al-Qur'an adalah agar mahasiswa mampu membaca al-Qur'an dengan baik dan benar serta hafal beberapa surat pendek dalam waktu dua semester. Sedangkan Kompetensi Dasar dari masing-masing pokok bahasan tidak ditentukan atau tidak ada kesepakatan antara pengelola, dosen dan lembaga. Kelemahan dari situasi ini adalah adanya ketidaksamaan hasil belajar yang dicapai oleh mahasiswa, berbeda dosen berbeda pula kemampuan yang dicapai.

\section{c. Materi Pembelajaran}

Materi pembelajaran dalam suatu kurikulum adalah segala sesuatu yang diberikan kepada peserta didik dalam kegiatan belajar mengajar dalam rangka mencapai tujuan. ${ }^{16}$ Isi kurikulum menurut Hamalik adalah bahan kajian atau pelajaran untuk mencapai tujuan penyelenggaraan satuan pendidikan yang bersangkutan. ${ }^{17}$ Silabus diajarkan dalam bentuk pokok-pokok bahasan dan sub pokok bahasan, serta uaraian bahan pelajaran itulah yang dijadikan dasar pengambilan bahan dalam setiap kegiatan belajar mengajar di kelas oleh guru. ${ }^{18}$ Ada kriteria yang harus dipenuhi dalam menentukan kurikulum, yaitu : Isi kurikulum harus sesuai, tepat dan bermakna bagi perkembangan peserta didik,

\footnotetext{
${ }^{14}$ Muhammad Zaini, MA, Pengembangan Kurikulum Konsep, Implementasi, Evaluasi dan Inovasi, (Yogyakarta : Teras, 2009), hlm.5-7.

${ }_{15}$ Nana Sudjana, Pembinaan dan Pengembangan Kurikulum di Sekolah, (Bandung : Sinar Baru Algensindo, 1996), hlm.22.

16 Burhan Nurgiantoro, Dasar-Dasar Pengembangan Kurikulum Sekolah, (Yogyakarta : BPFE UGM,1988), hlm.10.

${ }^{17}$ Hamalik, Kurikulum...., hlm.25.

${ }^{18}$ Nurdin, Guru Profesional...., hlm.54.
} 
harus mencerminkan kejadian dan fakta sosial, artinya sesuai dengan tuntutan hidup nyata dalam masyarakat, mengandung pengetahuan ilmiah yang komprehensif, mengandung aspek ilmiah yang tahan uji, mengandung bahan yang jelas, teori, prinsip, konsep dan fakta yang terdapat di dalamnya bukan sekedar informasi intelektual, dan harus dapat menunjang tercapainya tujuan pendidikan. Dalam menentukan urutan dalam kurikulum tentu harus memperhatikan faktor : kesulitan bahan pelajaran, pengalaman masa lampau atau yang telah dimiliki anak didik, tingkat kematangan fisik, mental atau kecerdasan anak, bakat dan minat anak. ${ }^{19}$

Pada program pembinaan membaca al-Qur'an di IAIN tidak ditemukan adanya materi pembelajaran atau isi kurikulum yang telah disepakati bersama oleh perancang program, untuk kemudian digunakan bersama-sama oleh dosen yang mengajar di kelas. Seharusnya sejak awal sudah dipersiapkan materi yang akan disampaikan di kelas yang disesuaikan dengan kemampuan awal mahasiswa yang dilihat dari hasil pre test mereka, lalu disesuaikan pula dengan tingkat pembinaannya, sehingga pada pembinaan satu, dua atau tiga, siapapun dosennya maka materi yang disampaikan adalah sama.

\section{d. Metode dan Model Pembelajaran}

Melalui metode pembelajaran yang tepat, materi pelajaran dapat disampaikan dengan efisien, efektif dan terukur dengan baik. Setiap pendekatan dan metode memiliki logikanya sendiri serta tujuan dan target yang khas pula. Penentuan dan pilihan terhadap sebuah metode dan pendekatan yang akan digunakan amat ditentukan oleh produk yang akan dihasilkan melalui metode yang digunakan itu. ${ }^{20}$ Saking pentingnya sebuah metode dalam pembelajaran, Mahmud Yunus pernah mengatakan bahwa metode itu lebih penting dari materi pembelajaran. Ali Syari'ati juga mengemukakan pentingnya metode melalui ungkapannya yang mengatakan bahwa sesorang boleh kehilangan sesuatu, tetapi tidak boleh kehilangan tentang metode mencari sesuatu itu. ${ }^{21}$

Ada beberapa faktor yang perlu dipertimbangkan dalam memilih metode pembelajaran yaitu : tujuan dan bahan pelajaran, peserta didik, lingkungan, alat dan sumber belajar dan kesiapan guru. ${ }^{22}$ Keberhasilan pembelajaran juga ditentukan oleh strategi pembelajaran. Strategi pembelajaran adalah langkah-langkah yang terencana dan bermakna luas dan mendalam serta berdampak jauh ke depan dalam menggerakkan seseorang agar dengan kemauan dan kemampuannya sendiri dapat melakukan kegiatan yang berhubungan dengan belajar.

\footnotetext{
${ }^{19}$ S. Nasution, Asas-Asas Kurikulum, (Jakarta : Bumi Aksara, 2001), hlm. 30-31.

20 Abuddin Nata, perspektif Islam Tentang Strategi Pembelajaran, Jakarta : Kencana Prenada Media Grup, 2009), hlm.180.

${ }^{21}$ Ali Syariati, Sosiologi Islam, (Bandung : Mizan, 1988), hlm.34.

22 Abuddin Nata, perspektif...., hlm.199-201.
} 
Berdasarkan hasil wawancara dengan beberapa mahasiswa, dosen dan pengelola, hasil observasi dan dokumentasi diperoleh fakta bahwa metode dan strategi yang paling sering dipakai oleh para dosen adalah metode ceramah dan demonstrasi. Mungkin kedua metode tersebut dipilih karena kedua metode tersebut adalah yang paling cocok untuk pengajaran al-Qur'an. Memang hal itu benar adanya, tetapi harus pula disadari, meskipun sebuah metode cocok untuk suatu materi pembelajaran tetapi kalau tidak dikombinasikan dengan metode lain, maka sebuah pembelajaran akan sangat membosankan. Oleh karena itu seharusnya metode yang digunakan haruslah bervariasi, supaya mahasiswa mendapatkan pengalaman belajar yang berbeda-beda setiap harinya. Di samping metode ceramah dan demonstrasi, bisa juga dipakai metode tanya jawab, metode penugasan, metode pemecahan masalah, metode diskusi, metode simulasi, metode eksperimen, dan metode penemuan (discovery inquiry).

Dalam hal strategi pembelajaran, terlihat bahwa dosen masuk kelas tanpa membawa strategi atau perencanaan yang matang. Mereka hanya megandalkan kemampuan mereka dalam penguasaan materi. Langkah-langkah pembelajaran yang harusnya dipersiapkan dengan matang untuk kemudian dilaksanakan pada saat pembelajaran, tidak lagi disiapkan. Hal ini karena mereka beranggapan bahwa karena sudah sering mengajar al-Qur'an maka tidak perlu lagi menyusun langkah-langkah pembelajaran, cukup dengan masuk lalu mempraktekkan apa yang selama ini sudah sering mereka lakukan pada saat mengajar al-Qur'an.

Untuk pendekatan pembelajaran, berdasarkan hasil wawancara dan observasi yang dilakukan oleh peneliti ditemukan fakta bahwa para dosen dalam melaksanakan pembelajaran sudah memadukan ketiga pendekatan dalam pembelajaran yaitu pendekatan pembelajaran individualistik, kelompok dan sosial. Hal ini bisa dilihat dari cara mereka memperlakukan para mahasiswa, pendekatan individual misalnya dilakukan ketika guru melihat bahwa kemampuan mahasiswa satu dengan mahsiswa lainnya berbeda-beda, demikian juga perilaku belajar mahasiswa, oleh karenanya cara menghadapi dan membimbing mereka pun berbeda-beda. Pada saat yang lain seorang dosen menggunakan pendekatan kelompok, misalnya menyatukan antara mahsiswa yang pintar dan mahsiswa yang tidak terlalu pintar, agar kemudian diharapkan mahsiswa yang sudah bisa mengaji dapat mengajarkan yang belum bisa mengaji, mereka ditugaskan membuat kelompok yang setiap kelompok terdiri dari mahsiswa yang sudah mahir membaca al-Qur'an dan yang belum mahir, kemudian mereka ditugaskan untuk mengaji setiap hari secara bersama-sama agar yang pintar bisa mengajarkan yang belum mahir.

Media pembelajaran merupakan segala bentuk perangsang dan alat yang disediakan guru untuk mendorong siswa belajar. Bentuk perangsang disini bisa berupa media audio, visual, media audio visual, papan, bagan, gambar, film, audio kaset, televisi, komputer, LCD, internet dan lain-lain. ${ }^{23}$ Rowntree dalam 
Sukmadinata mengelompokkan media mengajar menjadi lima macam yaitu ; interaksi insani, realita, pictorial, simbol tetulis dan rekaman suara. ${ }^{24}$ Media yang paling sering digunakan oleh dosen saat mengajar al-Qur'an hanya papan tulis dan spidol. Pada saat ditanyakan mengapa tidak menggunakan media lain, mereka menjawab karena tidak kebagian LCD, dan ada juga yang menjawab karena tidak ada bahan yang mau ditayangkan serta tidak perlu menggunakan media lain karena dengan menggunakan papan tulis dan spidol saja sudah cukup memberikan pemahaman pada mahasiswa.

e. Evaluasi

Evaluasi menurut B. S. Bloom seperti dikutip oleh Daryanto adalah pengumpulan fakta secara sistematis untuk menetapkan bahwa telah terjadi perubahan dalam diri siswa dan menetapkan tingkat perubahan tersebut. ${ }^{25}$ Ralph Tyler dalam arikunto menegaskan bahwa evaluasi adalah proses untuk mengetahui apakah tujuan pendidikan telah dapat terealisasikan. ${ }^{26}$ Evaluasi merupakan proses mengetahui ketercapaian dan keberhasilan pencapaian tujuan dari suatu program. Evaluasi juga merupakan proses pengukuran dan penilaian dari suatu kinerja penyelenggaraan program, apakah program tersebut berjalan dengan baik atau tidak.

Di sekolah sering dikenal dengan evaluasi formatif dan sumatif. Evaluasi formatif dimaksudkan untuk mengevaluasi setelah menyelesaikan satu pokok bahasan atau beberapa pokok bahasan. Adapun evaluasi sumatif dilakukan setelah semua kegiatan selesai di lakukan sesuai dengan waktu tertentu, misalnya satu semester, satu tahun, 6 tahun atau 3 tahun menempuh studi sesuai dengan jenjang sekolah. ${ }^{27}$ Pada program pembinaan Membaca al-Qur'an yang dilakukan oleh PUSQIK, kedua evaluasi tersebut di atas (evaluasi hasil belajar dan evaluasi proses) telah dilakukan. Evaluasi hasil belajar dilakukan satu kali yaitu pada akhir semester saja. Kemudian hasil tersebut disetorkan ke pengelola program yang ada di PUSQIK, lalu diumumkan kepada para mahasiswa. Bagi mahasiswa yang sudah lulus dipersilahkan untuk mengikuti program matrikulasi di tingkat berikutnya. Tidak ada evaluasi tengah semester. Adapun soal-soal ujian atau bentuk-bentuk evaluasi tidak ada panduan atau keseragaman antara satu dosen dengan dosen lainnya. Untuk evaluasi program hanya dilakukan satu kali dalam semester, yaitu pada awal semester. Evaluasi ini dilakukan dengan cara mengundang para dosen, ketua prodi atau ketua jurusan untuk rapat persiapan pelaksanaan program sekaligus mengevaluasi program yang sudah berjalan sebelumnya. Hanya saja pada pelaksanaannya, hanya 6-8 orang dosen saja yang datang untuk memenuhi undangan rapat tersebut. Pada saat

${ }^{24}$ Sukmadinata, Pengembangan..., hlm.108.

${ }^{25}$ Daryanto, Evaluasi Pendidikan, (Jakarta : Rineka Cipta, 1999), hlm.1.

${ }^{26}$ Suharsimi Arikunto dan Cepe Safrudin Abdul Jabar, Evaluasi Program Pendidikan Pedoman Teoritis dan Praktis Bagi Praktisi Pendidikan, (Jakarta : Bumi Aksara, 1997), Cet.II, hlm.4.

${ }^{27}$ Rambat Nur Sasongko dan Bambang Sahono, Desain Inovasi Manajemen Sekolah, Jakrta : Shani publisher, 2016), hlm.50. 
ditanyakan kepada dosen-dosen yang tidak hadir terkait dengan ketidakhadiran mereka, mereka menjawab karena rapat berbarengan dengan jadwal mengajar mereka. Ada juga yang menjawab karena tidak mendapat undangan, dan yang lain mengatakan tidak perlu datang karena yang dibicarakan adalah itu-itu saja dari tahun ke tahun.

Sementara itu hasil dari evaluasi, baik evaluasi hasil pembelajaran maupun evalusi proses pembelajaran tidak pernah disampaikan kepada prodi atau jurusan atau fakultas. Setelah ditanyakan kepada beberapa ketua prodi, mereka menjawab bahwa mereka tidak pernah menerima laporan dari penyelenggara program tentang hasil evaluasi, dan mereka juga mengatakan bahwa mereka pun tidak pernah diajak untuk mengevaluasi proses lalu mencari solusi dari problem-problem pembelajaran yang ditemui di lapangan, mereka hanya menerima surat pemberitahuan bahwa program akan dimulai dan diminta untuk menyediakan tempat dan waktu untuk tempat pelaksanaan program.

\section{f. Pendidik}

Dalam literatur pendidikan Islam, pendidik disebut ustadz, muallim, murabbi, mursyid, mudarris, muaddib, muzakki. Ini mengandung makna bahwa seorang guru dituntut untuk komitmen terhadap profesionalisme dalam mengemban tugasnya. Seorang dikatakan profesional bilamana pada dirinya melekat sifat dedikatif yang tinggi terhadap tugasnya, sikap komitmen terhadap mutu proses dan hasil kerja, serta sikap continous improvement yakni selalu berusaha memperbaiki dan memperbaharui model-model atau cara kerjanya sesuai dengan tuntunan zamannya secara berkelanjutan yang dilandasi oleh kesadaran yang tinggi bahwa tugas mendidik adalah tugas menyiapkan generasi penerus yang akan hidup pada zamannya di masa depan, sebagaimana pernyataan sahabat Ali bin Abi Talib : "Didiklah atau ajarilah anak-anakmu karena mereka diciptakan untuk zamannya di masa depan, bukan untuk zamanmu sekarang", 28

Seorang pendidik harus memiliki kompetensi, yang meliputi kompetensi akademik atau profesional yang terkait dengan bidang keahlian ilmu yang akan diajarinya, kompetensi pedagogik yang terkait dengan kemampuan menyampaikan ilmu tersebut secara efektif dan efisien, kompetensi kepribadian yang terkait dengan akhlak dan kepribadian guru, dan kompetensi sosial yang terkait dengan kemampuan guru dalam membangun komunikasi, interaksi dan kerjasama dengan masyarakat, serta mendayagunakannya untuk keperluan pendidikan. Dengan berbagai kompetensi tersebut maka seorang guru akan dapat melaksanakan tugasnya secara profesional. ${ }^{29}$

${ }_{28}$ Muhaimin, Pemikiran dan Aktualisasi Pengembangan Pemikiran Islam, (Jakarta : Rajawali Pers, 2012), hlm. 173. hlm.92.

29 Abuddin Nata, Pemikiran pendidikan Islam dan Barat, (Jakarta : Rajawali Pers, 2013), 
Terkait dengan pendidik pada program pembinaan al-Qur'an oleh PUSQIK, setelah dilakukan wawancara dengan mahasiswa ditemukan fakta bahwa para dosen sering terlambat masuk bahkan sering tidak masuk. Ketika ditanya lebih dalam frekuensi keterlambatan dosen lebih dari $50 \%$ dan ketidakhadiran dosen lebih dari 30\%. Pada saat dikonfirmasi dengan dosen, mereka mengatakan jadual pembinaan berbarengan dengan jadual mengajar mata kuliah lain di kelas yang berbeda. Penyebab dari kasus ini adalah tidak adanya komunikasi yang intens antara pengelola (dalam hal ini PUSQIK) dan pengelola prodi, sehingga dosen yang sudah dijadwalkan di prodi untuk mengajar mata kuliah lain dijadwalkan lagi untuk mengajar pembinaan al-Qur'an di kelas yang lain dalam jam dan hari yang sama. Sementara untuk pindah jam atau hari lain sudah tidak bisa lagi, karena akan bentrok dengan jadwal yang lainnya lagi.

Persoalan lain yang terkait dengan pendidik adalah tidak seimbangnya antara jumlah dosen dan mahasiswa yang mengikuti program. Dengan 1400 mahasiswa yang ikut program hanya dibimbing oleh 42 orang dosen, hal ini berarti rasio antara dosen dan mahasiswa adalah 1 banding 33, 3. Ini berarti satu orang dosen harus membina 34 orang mahasiswa, kenyataan yang sangat jauh dari ideal, karena idealnya satu orang dosen membimbing maksimal 20 orang mahasiswa. Kekurangan dosen ini disebabkan oleh kurangnya dana dan SDM yang memang tidak tersedia.

\section{g. Peserta Didik}

Peserta didik dalam pendidikan Islam sama halnya dengan teori Barat, adalah individu yang sedang tumbuh dan berkembang, baik secara fisik, psikologis, sosial, dan religius dalam mengarungi kehidupan di dunia dan akhirat kel;ak. Definisi tersebut memberi arti bahwa peserta didik merupakan individu yang belum dewasa yang karenanya memerlukan orang lain untuk menjadikan dirinya dewasa. Anak kandung adalah peserta didik dalam keluarga, murid adalah peserta didik di sekolah, anak-anak penduduk adalah peserta didik masyarakat sekitarnya, dan umat beragama menjadi peserta didik ruhaniawan dalam suatu agama. ${ }^{30}$

Dalam proses belajar mengajar seorang pendidik harus sedapat mungkin memahami hakikat peserta didiknya sebagai subyek dan obyek pendidikan. Kesalahan dalam memahami hakikat peserta didik menjadikan kegagalan dalam proses pendidikan. Menurut Al Ghozali ada sebelas sifat dan kode etik peserta didik dalam pendidikan Islam : Belajar dengan niat ibadah kepada Allah, mengurangi kecenderungan terhadap duniawi, memiliki sikap tawaddhu', menjaga pikiran dan pertentangan yang muncul, mempelajari ilmu yang terpuji maupun ilmu duniawi maupun ukhrawi, belajar dengan bertahap dan berjenjang, belajar ilmu sampai tuntas, mengenal nilai-nilai ilmiah dari sebuah

\footnotetext{
${ }^{30}$ Muhammad Muntahibun Nafis, Ilmu Pendidikan Islam, (Yogyakarta :Teras, 2011), hlm.
} 119. 
ilmu yang dipelajari, memprioritaskan ilmu yang terkait dengan kewajiban kepada Allah, mengenal nilai-nilai pragmatis bagi suatu ilmu pengetahuan, harus tunduk dan patuh pada nasehat guru. ${ }^{31}$

Dalam program pembinaan Membaca al-Qur'an oleh PUSQIK, peserta didik berasal dari berbagai latar belakang pendidikan, mereka terdiri dari lulusan SMA, Madrasah Aliyah atau Sekolah Menengah kejuruan. Dari 2000-an mahasiswa baru, 1400 diantaranya adalah mahasiswa yang belum bisa membaca al-Qur'an dengan baik dan benar. Mereka ini dibagi menjadi tiga tingkatan belajar yaitu pembinaan 1, pembinaan 2 dan pembinaan 3. Pembagian tingkat pembinaan berdasarkan kemampuan awal membaca al-Qur'an yang diketahui dari hasil test membaca al-Qur'an pada saat mereka mengikuti seleksi masuk IAIN. Hanya saja hasil test membaca al-Qur'an yang mendompleng pada seleksi masuk tersebut tidak betul-betul menggambarkan kemampuan mahasiswa sesungguhnya dalam hal membaca al-Qur'an. Misalnya ada mahasiswa yang belum mampu membaca al-Qur'an dengan baik dan benar, tetapi hasil testnya dinyatakan bagus, kemudian mahasiswa tersebut ditempatkan pada pembinaan 2 atau 3, hal ini sangat menyulitkan bagi dosen pengampu, karena selisih kemampuan awal yang sangat jauh tetapi harus mengejar target dan tujuan yang sama dengan mahaiswa lain yang lebih baik bacaannya.

Persoalan lain yang muncul adalah minat dan motivasi mahasiswa yang sangat rendah. Pada dasarnya mereka sadar bahwa mereka membutuhkan pembinaan membaca al-Qur'an, hanya saja jadwal yang bentrok dengan jadual kuliah mata kuliah lain, atau bentrok dengan ekstrakurikuler (seperti futsal, bola volly dll) membuat mereka tidak bisa mengikuti program dengan maksimal. Faktor lain yang menyebabkan mahasiswa tidak mengikuti kegiatan pembinaan dengan maksimal adalah karena mata kuliah pembinaan al-Qur'an merupakan mata kuliah yang 0 SKS dan tidak ada hukuman atau konsekuensi jika mereka tidak mengikuti program tersebut. Bahkan jika mereka tidak lulus pun tidak ada sanksi yang mereka terima. Hal lain yang membuat mahasiswa tidak rajin mengikuti pembinaan adalah kelas yang selalu berpindah-pindah. Berdasarkan hasil wawancara dan observasi ditemukan fakta bahwa kelas yang tercantum pada jadual pembinaan yang dibuat oleh PUSQIK ternyata sudah terjadual di sistem siakad dipakai oleh dosen lain untuk mata kuliah yang lain. Hal ini menyebabkan pelaksanaan pembinaan berpindah-pindah mencari kelas lain yang kosong. Beberapa kali program tidak terlaksana karena kelas dipakai semua, tidak ditemukan kelas yang kosong.

1. Keberhasilan Program Pembinaan Membaca al-Qur'an di IAIN Bengkulu.

Peserta program pembinaan Membaca al-Qur'an sebanyak 1400 mahasiswa. Dari populasi tersebut peneliti mengambil sampel sebanyak 10\% dari populasi, yang berarti sebanyak 140 orang mahasiswa, responden diambil

${ }^{31}$ Muhammad Muntahibun Nafis, Ilmu Pendidikan...., hlm. 132. 
secara acak dari semua fakultas. Dari angket dan test yang dilakukan diperoleh hasil 33,3\% dari mahasiswa telah berhasil mencapai tujuan pembelajaran, 27,7\% dengan tingkat keberhasilan sedang dan 39\% dengan tingkat keberhasilan rendah. Dengan demikian dapat dikatakan bahwa tingkat keberhasilan program pembinaan Membaca al-Qur'an oleh PUSQIK tidak mencapai 50\%. Adapun faktor yang mendukung keberhasilan program adalah; 1) kesungguhan belajar dari mahasiswa, 2) keseriusan dan kesungguhan para pengajar dan 3) kesungguhan dari para pengelola. Sementara itu dari data yang diperoleh dari PUSQIK, keberhasilan program dapat dilihat pada tabel berikut:

\section{Daftar Kelulusan Peserta Pembinaan membaca al-Qur'an}

\begin{tabular}{|l|l|l|l|l|l|}
\hline & Fakultas & Pembinaan 1 & Pembinaan 2 & Pembinaan 3 & Persentase \\
\hline 01 & FEBI & $6 \mathrm{mhs}$ & $31 \mathrm{mhs}$ & $78 \mathrm{mhs}$ & $30,8 \%$ \\
\hline 02 & FUAD & $4 \mathrm{mhs}$ & $1 \mathrm{mhs}$ & $4 \mathrm{mhs}$ & $3,91 \%$ \\
\hline 03 & Syari'ah & $1 \mathrm{mhs}$ & $127 \mathrm{mhs}$ & $12 \mathrm{mhs}$ & $40,46 \%$ \\
\hline 04 & FTT & $18 \mathrm{mhs}$ & $72 \mathrm{mhs}$ & $243 \mathrm{mhs}$ & $57,41 \%$ \\
\hline
\end{tabular}

Dari tabel di atas dapat dilihat bahwa pada tiga Fakultas yaitu FEBI, FUAD dan Syariah tingkat kelulusan berada di bawah 50\%, hanya fakultas Tarbiyah dan Tadris saja yang mencapai kelulusan 50\%, sementara itu rata-rata kelulusan dari semua fakultas hanya $38,96 \%$ saja.

Peserta program pembinaan membaca al-Qur'an yang diadakan oleh PUSQIK pada semester ganjil tahun 2016 secara keseluruhan berjumlah 1532 mahasiswa, dengan rincian : fakultas Ekonomi dan Bisnis Islam terdiri dari 376 mahasiswa, Fakultas Ushuluddin, Adab dan Dakwah 230 mahasiswa, fakultas Syariah dan Hukum Islam 346 dan fakultas Tarbiyah dan Tadris 580 mahasiswa. Dari sekian banyak mahasiswa yang mengikuti program tersebut yang lulus atau naik ke tingkat berikutnya hanya 597 mahasiswa, dengan rincian fakultas Ekonomi dan Bisnis Islam sebanyak 115 mahasiswa, Fakultas Ushuluddin, adab dan Dakwah sebanyak 9 mahasiswa, fakultas Syariah dan Hukum Islam sebanyak 140 mahasiswa dan Fakultas Tarbiyah dan Tadris sebanyak 333 mahasiswa.

\section{Penutup}

Program pembinaan Membaca Al-Quran yang dilaksanakan oleh Ma'had al Jamiah dan PUSQIK merupakan program yang sangat bermanfaat bagi mahasiswa. Karena dengan program tersebut mahasiswa menjadi sangat terbantu untuk memperbaiki atau meningkatkan kemampuan membaca alQuran mereka. Hanya saja dalam pelaksanaannya mengalami banyak kendala, mulai dari masalah pendanaan, perencanaan yang kurang matang, tidak tersedianya silabus, metode yang monoton, jadual yang bentrok dengan mata kuliah lain, tempat yang berpindah-pindah, kehadiran dosen, kedisiplinan mahasiswa, koordinasi yang kurang dan lain-lain. Kendala-kendala tersebut 
sangat mempengaruhi keberhasilan pencapaian tujuan diadakannya program tersebut. Dari 1532 mahasiswa yang mengikuti program pembinaan yang dimaksud hanya 597 mahasiswa saja yang dinyatakan lulus atau naik ke pembinaan selanjutnya. Tingkat kelulusan hanya 38,97\% . (39,96\%)

\section{Daftar Pustaka}

Abuddin Nata. Pemikiran pendidikan Islam dan Barat. Jakarta: Rajawali Pers, 2013.

Abuddin Nata. Perspektif Islam Tentang Strategi Pembelajara. Jakarta: Kencana Prenada Media Grup, 2009.

Ali Syariati. Sosiologi Islam. Bandung: Mizan, 1988.

Arif S Sadiman dkk. Media Pendidikan. Jakarta: Raja Grafindo Persada, 1996.

Burhan Nurgiantoro. Dasar-Dasar Pengembangan Kurikulum Sekolah. Yogyakarta: BPFE UGM,1988.

Daryanto. Evaluasi Pendidikan. Jakarta: Rineka Cipta, 1999.

Jerold E Kemp. Proses Perancangan Pengajaran, terjemahan Asril Marjohan. Bandung : Penerbit ITB, 1994.

Koentjaraningrat. Metode-Metode Penelitian Masyarakat. Jakarta: Gramedia Edisi III, 1997.

Marvin D. Alcom and James M.Linely. Issus in Curriculum Development. New York: World Book Co., 1959.

Muhaimin. Pemikiran dan Aktualisasi Pengembangan Pemikiran Islam. Jakarta: Rajawali Pers, 2012.

Muhaimin, Wacana Pengembangan Pendidikan Islam. Yogyakarta: Pustaka Pelajar, 2004.

Muhammad Muntahibun Nafis. Ilmu Pendidikan Islam. Yogyakarta:Teras, 2011.

Muhammad Zaini. Pengembangan Kurikulum Konsep, Implementasi, Evaluasi dan Inovasi. Yogyakarta: Teras, 2009.

Nana Sudjana. Pembinaan dan Pengembangan Kurikulum di Sekolah. Bandung : Sinar Baru Algensindo, 1996), hlm.22.

Rambat Nur Sasongko dan Bambang Sahono. Desain Inovasi Manajemen Sekolah. Jakrta: Shani publisher, 2016.

Robert C. Bogdan dan Steven Taylor. Introduction to Kualitatif reaseach Method. New Jersey: John Willey and Son, 1984.

S.Nasution. Asas-Asas Kurikulum. Jakarta: Bumi Aksara, 2001.

Suharsimi Arikunto dan Cepe Safrudin Abdul Jabar. Evaluasi Program Pendidikan Pedoman Teoritis dan Praktis Bagi Praktisi Pendidikan. Jakarta: Bumi Aksara, 1997.

Howard M. Federspiel. Kajian Al-Qur'an di Indonesia. Bandung: Mizan, 1996.

M. Yusuf Musa. Al-Qur'an dan Filsafat. Yogyakarta: Tiara Wacana, 1991.

Sugiyono. Metode Penelitian Manajemen. Bandung: Alfabeta, 2015.

Sugiyono. Memahami Penelitian kualitatif. Bandung: ALFABETA, 2007. http://dedifathurohmah.blogspot.co.id/2015/10/pengajaran-danpembelajaran-al-Qur'an.html. didownload tal 07 Februari 2017. 